tables. The Bureau will also investigate file organization, to develop means for storing specific categories of data, and will continue previous work on extending and mechanizing various linear notations. The research group will work in close co-ordination with the research and development group of the Chemical Abstracts Service, which is also supported by a contract from the Chemical Information Programme.

\section{Jena Review}

'THE Jena Review (Jenaer Rundschau, as it is more widely known) was first published in 1956 and has recently celebrated its tenth anniversary in a number to which no less than seven Nobel Prizewinners contribute (Jena Review. VEB Carl Zeiss Jena. VEB Verlag Technik, Oranienburger Str. 13/14, Berlin C 2. No. 5; 1965). This enterprising house journal is now available in English, French, Russian and Spanish, besides the original German. Following the editorial by Dr. H. Schrade entitled "Ten Years of Jena Review", articles by the seven eminent scientists are: "The 'False Trans-uranic" Elements", by Dr. O. Hahn, Göttingen ; "Stable Isotopes", by Dr. G. Hertz, Berlin; "Symmetry and Invariance", by Dr. E. P. Wigner, Princeton, New Jersey; "The Part played by Pure Science and the Progress in High-Energy Physies", by Dr. C. P. Powell, Bristol; "Critical Opalescence", by Dr. P. J. W. Debye, Ithaca, New York; "Seeing and the Nature of Light", by Sir C. V. Raman, Bangalore; and "Celebration of the Award of the 1964 Nobel Prizes", by Dr. A. Tiselius, Uppsala. Other contributions are "Structure of Liquids and the Formation of Glass", by Dr. W. A. Weyl, Pennsylvania State University; "The Importance of Walter Nernst", by Dr. K. Schwabe, Dresden; and an obituary notice of the late Dr. Hans Boegehold, for 57 years with Zeiss, by Dr. H. Schrade. Jena Review appears bi-monthly; it is always well printed and produced, and the illustrations, both in black-andwhite and in colour, are of consistently high quality. Although originally founded to be " . . . a bridge and a linking of all the friends of the scientific and technical work of VEB Carl Zeiss Jena to all users of Zeiss equipment in every country throughout the world", in which aspiration it has certainly succeeded, this magazine is never a collection of explanatory advertisements; it is a welcome vehicle of up-to-date technical information, especially in the field of optical instruments and physies.

\section{The Museums Journal}

THE December issue of The Museums Journal follows the pattern of previous issues and is mainly devoted to a single theme $(65$, No. $3 ; 1965)$. The articles help to define some areas of work with art collections. One concerns a regional art collection and the problems it poses of balance and specialization, while another depicts the work of an art dealer from his side of the desk. The applied arts are no less complex than the fine arts, and a paper on furniture introduces a field of study which has recently generated a new society devoted to its history. The new processes used for the reproduction of relatively large numbers of lithographs are described. All these articles will help reflection on the role of a curator in an art gallery. The concluding article describes museum and art gallery buildings erected between 1845 and 1914 .

\section{Sarawak Museum}

The Sarawak Museum Journal, edited by the curator, Mr. Tom Harrisson, includes an interesting set of papers, among which is a comprehensive study of the Sarawak Malays by the editor (11, Nos. 23-24. (New series.) Pp. xii $+34 \mathrm{I}-666$. July-December 1964. 5 dollars: 12s.6d.). This paper will form the opening chapters of a book on the subject to be published in 1966. Other articles include notes on the descent of some Saribas
Malays, Sarawak Malay pottery, some Baram coffin burials, Papuan stone adzes, an introductory vocabulary of Suluk, Sarawak relations with Britain 1858-70 and Borneo maps of sixteenth and seventeenth centuries.

\section{Transvaal Museum}

The Annals of the Transvaal Museum comprises an account by Hans John (Germany) of the species of the coleopterous family Discolomidae collected between 1960 and 1962 during field research on the humicolous fauna (25, No. 1: Südafrikanische Discolomidae (Coleoptera). Von Hans John. Pp. 19. Pretoria: Transvaal Museum, 1965). Included also is a paper by Jean Thérond (France), detailing the species collected in Southern Africa during recent Transvaal Museum expeditions (25, No. 2. Pp. 14).

\section{The National Central Library}

THE forty-ninth annual report of the Executive Committee of the National Central Library covers the year ended March 31, 1965, in which the number of applications increased to $119,468(107,742$ in $1963-64)$, 77 per cent being satisfied, comparod with $78 \cdot 75$ per cent in 1963-64 (Pp. 24. London: The National Central Library, 1965). Of the applications, 92,844 were for books and 26,844 for periodicals: of those satisfied, 38,318 came from public libraries, 20,895 from university libraries, 12,007 from special outlier libraries, 2,608 from Government libraries and 4,727 from overseas libraries. British libraries made 4,150 loans to overseas libraries $(3,739$ in $1963-64)$ and borrowed 3,863 items from overseas $(3,488$ in 1963-64); 577 photocopies wore supplied to foreign libraries and 1,417 obtained. Of the fifty-eight lending countries, West Germany was the chief, followed by the Soviet Union. the United States, East Germany and France. West Germany was also the principal of 36 borrowers, followed. by Hungary, the Soviet Union, Denmark, Czechoslovakia and East Germany. The United States was the chief source of photocopies and Bulgaria the chiof recipient. The 384 outlier libraries satisfied 21,278 applications, and other special libraries another 8,313. In addition to 24,468 loans made at the direct request of the National Central Library, university libraries lent 17,445 items as members of regions. A further 15,000 books were catalogued and housed at the Woolwich building, bringing the total to 82,000, and the Survey of Applications, January $1-J$ une 30,1964 , is now being examined by the Executive Committee. The first stage of the unification of the catalogues was completed and the British Union Catalogue of Periodicals was continued from 1960 on a new basis. The Treasury grant for the year was $£ 105,000$ ( $£ 95,000$ in 1963-64). The National Committeo on Regional Library Co-operation and the Implementation Committee both met twice during the year.

\section{Indexes and Indexing}

OF how many authors of scientific books can it be said with Goldsmith that "He writes indexes to perfection"? 'Time and again reviewers are critical of the adequacy (or' lack of adequacy) of the index to a volume crammed full of academic or technical detail, of which the contents page or chapter headings suffice for direction, with perhaps only a skeleton index to the main subjects to assist the reader. Codes of practice exist as guidance to authors in preparing scientific papers for publication, on the style in which they should be presented, on the proper arrangement of references and quotations, even to instructions on desirable forms of illustration; but there are still no precepts generally accepted, let along followed, on the subject of indexing for its own and especially for the reader's sake; this, despite a British Standard on Alphabetical Arrangement, which is a sct of rules designed to secure uniformity in the alphabetical arrangemont of items in indexes, catalogues and lists of all kinds (1749; 